\title{
Influence of Iron Deficiency Anemia on HbA1c: A Review
}

\author{
Amreen Naqash and Ghulam N Bader* \\ Department of Pharmaceutical Sciences, University of Kashmir, India
}

Submission: January 15, 2018; Published: January 25, 2018

*Corresponding author: Ghulam N Bader, Department of Pharmaceutical Sciences, University of Kashmir, Srinagar, J \& K, India, Tel: +91-9419055344; Fax: +91-194-2415041; Email: gnbader@kashmiruniversity.ac.in

Abstract

Hemoglobin A1c (HbA1c) is widely used as a diagnostic tool for diabetes. Many clinical conditions affect erythrocyte turnover which influence HbA1c levels. These levels are lowered by different forms of anemia, but reverse is the case in iron deficiency anemia (IDA). This is suggested by various studies which propose an increase in HbA1c levels in patients with IDA. However, there are studies which negate any influence of IDA over HbA1c levels. In both cases the clinical data is not sufficient to confirm or nullify the role of IDA in increasing HbA1c levels.

\section{Introduction}

Hemoglobin A1c (HbA1c), a glycated hemoglobin is formed by an irreversible, slow non-enzymatic catalysis of the $\beta$ chain of globin in mature hemoglobin ( $\mathrm{Hb}$ ) [1,2]. It is used as a gold standard for monitoring glycemic status for the previous three months (the life span of a red blood cell) in patients with diabetes [3]. HbA1c provides an integrated measure of glycemia which is less susceptible to short-term modulation than blood glucose levels. Also, it helps to keep a track of diabetic therapy within individuals suffering from diabetes. WHO and ADA have approved the use of HbA1c determination for diagnosis of type 2 diabetes $[4,5]$. The normal range of $\mathrm{HbA} 1 \mathrm{c}$ in a healthy person is 4 to $6 \%[6]$.

Clinically there are three major factors on which $\mathrm{HbA1c}$ levels depend.

A. HbA1c in reticulocytes when released from the bone marrow;

B. Hb glycation rate as red blood cells (RBCs) become older a function of glucose concentration to which $\mathrm{Hb}$ is exposed; and

C. The mean age of RBCs in the circulation [7].

HbA1c levels can be affected by number of factors such as structural hemoglobinopathies, thalassemia syndrome, and alteration in quaternary structure of $\mathrm{Hb}$ [8]. Also, HbA1c levels can be changed by different types of anemia [9]. Anemia is the most prevalent form of nutritional deficiency both in developed and developing countries. Globally, $50 \%$ of anemic burden is contributed alone by Iron deficiency $[10,11]$. The clinical profile of many systemic diseases is regulated by the iron [12], which is involved in most important metabolic processes viz. transportation of oxygen, regulation of cell growth and differentiation, deoxyribonucleic acid (DNA) synthesis, and electron transport $[13,14]$.

Iron deficiency anemia (IDA) can increase the red blood cell turnover which can increase glycation of $\mathrm{Hb}$ leading to higher HbA1c values as observed in blood loss, hemolysis, hemoglobinopathies, red cell disorders and myelodysplastic disease [15]. There are studies to support the idea that diabetes is influenced by changes in the iron level in a body [16]. Lower levels of serum iron or serum ferritin have been linked with increased glycation of $\mathrm{HbA1c}[17,18]$. It has been reported that there is a bidirectional relationship between iron metabolism and glucose homeostasis, higher iron levels modulate both the action and secretion of insulin [12]. Thus, lower the iron levels, higher is the glycation of $\mathrm{HbA1C}$, leading to its false-high values in diabetic as well as non-diabetic individuals [19].

Brooks et al. [20] reported that a relative absence of iron results in the alteration of quaternary structure of the $\mathrm{Hb}$ molecule leading to excessive glycation of the beta globin chain. In another study by Sluiter et al. [21] it was reported that glycation of $\mathrm{Hb}$ is an irreversible process thus, with the aging of a cell there is a linear increase of $\mathrm{HbA1c}$ in the erythrocyte. El Agouza et al. 


\section{Current Research in Diabetes \& Obesity Journal}

[22] reported that at a constant glucose level, lower levels of $\mathrm{Hb}$ can lead to an increase in the glycated fraction because HbA1c is measured as a percentage of total $\mathrm{HbA}$. These studies report relationship between IDA and $\mathrm{HbA} 1 \mathrm{c}$ on the basis of structural modification of $\mathrm{Hb}$ and $\mathrm{HbA1c}$ levels in old and new red blood cells [20]. Coban et al. [19] in his studies showed that patients with IDA had higher HbA1c levels and on treatment with iron these levels significantly decreased. A case study by Mudenha et al. [23] reported that $\mathrm{HbA1c}$ levels significantly decreased with correction of IDA. Furthermore, Silva et al. [24] and Rajagopal et al. [7] reported difference in HbA1c levels among diabetic as well as non diabetic patients with mild, moderate, and severe IDA.

On the other hand, Heyningen et al. [25] and Hansen et al. [25] reported that there was no difference between HbA1c levels in patients with IDA and control. These findings gather support from study by Rai et al. [26], who reported no difference in $\mathrm{HbA1c}$ levels with respect to IDA using different methods to assay HbA1c. Thus these conflicting reports are enough to create a stir in the minds of clinicians regarding a successful therapy in diabetic patients with IDA. Hence the effect of IDA on HbA1c needs to be evaluated at mechanistic level, so as to be assured about the outcome of the therapy. Iron replacement therapy in diabetic patients with IDA needs to be considered.

\section{Conclusion}

IDA is the commonest nutritional deficiency worldwide but the prevalence is higher in developing countries, and most vulnerable groups to IDA are women, children and adolescents [27]. Also, in low and middle income countries diabetes too is increasing and the mostly affected age group is 45-64 years [28]. So, determination of $\mathrm{HbA1c}$ levels has increased for both screening and diagnosis of diabetes. Clinicians need to evaluate the nonglycemic factors that could affect the HbA1c levels of a patient $[29,30]$. Different types of anemia can have a negative effect on HbA1c levels, some investigators have shown that IDA increases the $\mathrm{HbA1c}$ levels independent of fasting glucose level [16] whereas others have negated these findings. In either case the clinical data is not sufficient and further studies are required to identify the role of erythrocyte indices in modulation of $\mathrm{HbA1c}$ levels. Studies with large population need to be conducted to evaluate the difference between severity and effects of IDA on HbA1c values.

\section{References}

1. Higgins T (2012) HbA(1c)--an analyte of increasing importance. Clin Biochem 45(13-14): 1038-1045.

2. Nitin S (2010) HbA1c and factors other than diabetes mellitus affecting it. Singapore Med J 51(8): 616-622.

3. Florkowski C (2013) HbA(1c) as a Diagnostic Test for Diabetes Mellitus - Reviewing the Evidence. Clin Biochem Rev 34(2): 75-83.

4. WHO (2011) Use of Glycated Haemoglobin (HbA1c) in the Diagnosis of Diabetes Mellitus: Abbreviated Report of a WHO Consultation. Geneva World Heal Organ.
5. American Diabetes Association (2013) Standards of Medical Care in Diabetes-2013. Diabetes Care 36(Suppl 1):S11-S66.

6. Abass AE, Musa IR, Rayis DA, Adam I, Gasim IG (2017) Glycated hemoglobin and red blood cell indices in non-diabetic pregnant women. Clin Pract 7(4): 999.

7. Rajagopal L (2017) Does Iron Deficiency Anaemia and its Severity Influence HbA1C Level in Non Diabetics? An Analysis of 150 Cases. Journal of Clinical and Diagnostic Research 11(2).

8. Goldstein DE, Little RR, Lorenz RA, Malone JI, Nathan D, et al. (2004) Tests of Glycemia in Diabetes. Diabetes Care 27(7): 1761-1773.

9. English E, Idris I, Smith G, Dhatariya K, Kilpatrick ES, et al. (2015) The effect of anaemia and abnormalities of erythrocyte indices on HbA1c analysis: a systematic review. Diabetologia 58(7): 1409-1421.

10. Soliman AT, Sanctis V De, Yassin M, Soliman N (2017) Iron deficiency anemia and glucose metabolism. Acta Biomed 88(1): 112-118.

11. Naqash A, Ara R, Bader GN (2018) Effectiveness and safety of ferric carboxymaltose compared to iron sucrose in women with iron deficiency anemia: phase IV clinical trials. BMC Womens Health 18(1): 6.

12. Schindler C, Birkenfeld AL, Hanefeld M, Schatz U, Köhler C, et al. (2017) Intravenous Ferric Carboxymaltose in Patients with Type 2 Diabetes Mellitus and Iron Deficiency: CLEVER Trial Study Design and Protocol. Diabetes Therapy, pp. 1-11.

13. Finch C (1994) Regulators of iron balance in humans. Blood 84(6): 1697-1702.

14. Abbaspour N, Hurrell R, Kelishadi R (2014) Review on iron and its importance for human health. J Res Med Sci 19(2): 164-174.

15. Franco RS (2009) The measurement and importance of red cell survival. Am J Hematol 84(2): 109-114.

16. Ahmad J, Rafat D (2013) HbA1c and iron deficiency: A review. Diabetes Metab Syndr Clin Res Rev 7(2): 118-122.

17. Christy AL, Manjrekar PA, Babu RP, Hegde A, Rukmini MS (2014) Influence of iron deficiency anemia on hemoglobin A1c levels in diabetic individuals with controlled plasma glucose levels. Iran Biomed J 18(2): 88-93.

18. Hashimoto K, Nogu chi S, Morimoto Y, Hamada S, Wasada K, et al. (2008) A1C but not serum glycated albumin is elevated in late pregnancy owing to iron deficiency. Diabetes Care 31(10): 1945-1948.

19. Coban E, Ozdogan M, Timuragaoglu A (2004) Effect of iron deficiency anemia on the levels of hemoglobin A1c in nondiabetic patients. Acta Haematol 112(3): 126-128.

20. Brooks AP, Metcalfe J, Day JL, Edwards MS (1980) Iron deficiency and glycosylated haemoglobin A. Lancet 2(8186): 141.

21. Sluiter WJ, van Essen LH, Reitsma WD, Doorenbos H (1980) Glycosylated haemoglobin and iron deficiency. Lancet 2(8193): 531532 .

22. El Agouza I, Abu Shahla A, Sirdah M (2002) The effect of iron deficiency anaemia on the levels of haemoglobin subtypes: possible consequences for clinical diagnosis. Clin Lab Haematol 24(5): 285-289.

23. Mudenha ET, Aarella VG, Chandrasekaram S, Fernando DJS (2016) Rising HbA1c in the presence of optimal glycaemic control as assessed by self-monitoring - iron deficiency anaemia. JRSM Open 7(2): 2054270415619321.

24. Silva JF, Pimentel AL, Camargo JL (2016) Effect of iron deficiency anaemia on HbA1c levels is dependent on the degree of anaemia. Clin Biochem 49(1-2): 117-120.

25. Sinha N, Mishra TK, Singh T, Gupta N (2012) Effect of Iron Deficiency Anemia on Hemoglobin A1c Levels. Ann Lab Med 32(1): 17-22. 


\section{Current Research in Diabetes \& Obesity Journal}

26. Rai KB, Pattabiraman TN (1986) Glycosylated haemoglobin levels in iron deficiency anaemia. Indian J Med Res 83: 234-236.

27. Naqash A, Ara R, Bader GN (2017) Etiology, Treatment and Prevention of Iron Deficiency Anaemia (IDA) In Women : A Review 4(August).

28. Fazili I, Tanvir M, Naqash A, Bader GN (2017) Incidence and pattern of diabetes and pharmacoeconomic analysis of antidiabetic drug therapy at a tertiary care hospital. EJPMR 4(6): 468-472.
29. Kim C, Bullard KM, Herman WH, Beckles GL (2010) Association between iron deficiency and A1C Levels among adults without diabetes in the National Health and Nutrition Examination Survey, 1999-2006. Diabetes Care 33(4): 780-785.

30. Rafat D, Rabbani TK, Ahmad J, Ansari MA (2012) Influence of iron metabolism indices on HbA1c in non-diabetic pregnant women with and without iron-deficiency anemia: effect of iron supplementation. Diabetes Metab Syndr 6(2): 102-105.

\begin{tabular}{l} 
Your next submission with Juniper Publishers \\
will reach you the below assets \\
- Quality Editorial service \\
- Swift Peer Review \\
- Reprints availability \\
- E-prints Service \\
- Manuscript Podcast for convenient understanding \\
- Global attainment for your research \\
- Manuscript accessibility in different formats \\
( Pdf, E-pub, Full Text, Audio) \\
- Unceasing customer service \\
Track the below URL for one-step submission \\
https://juniperpublishers.com/online-submission.php \\
\hline
\end{tabular}

